\title{
Downstream Migrations of Juvenile Salmon and Other Fishes in the Upper Yukon River
}

\author{
MICHAEL J. BRADFORD, ${ }^{1}$ JAKE DUNCAN ${ }^{2}$ and JEAN W. JANG ${ }^{3}$
}

(Received 15 May 2007; accepted in revised form 9 November 2007)

\begin{abstract}
The Yukon River is the fourth largest river in North America, yet the ecology of its fishes has not been well described. During the spring and summer of 2002-04, we sampled the downstream migrations of fishes in the Yukon River mainstem near the Canada-U.S. border, using a rotary auger trap. Age-0 juvenile chinook salmon, Oncorhynchus tshawytscha, were the most common fish in the catch, and they peaked in abundance in mid-June. Smaller numbers of age- 1 chinook salmon and age-0 chum salmon, O. keta, were caught earlier in the season. Over $80 \%$ of the remaining catch consisted of young-of-theyear Coregoninae (whitefish), presumably moving from natal areas to summer rearing habitats. Few adult whitefish were captured, probably because our sampling terminated before fall spawning migrations began. Both juveniles and adults were captured for six other winter or spring spawning species that we encountered. Our results indicate that the Yukon River mainstem is used extensively as a migration corridor. This reach of the mainstem has very high suspended sediment levels in summer; its significance as rearing habitat remains unknown. Further studies are required to delineate the extent of migrations and the population structure for the non-anadromous species.
\end{abstract}

Key words: Yukon River, migration, chinook salmon, Oncorhynchus tshawytscha, chum salmon, Oncorhynchus keta, whitefish, Coregonus spp., Prosopium spp., inconnu, Stenodus leucichthys, arctic lamprey, Lampetra camtschatica, arctic grayling, Thymallus arcticus

RÉSUMÉ. Le fleuve Yukon est le quatrième plus grand fleuve de l'Amérique du Nord et pourtant, l'écologie de ses poissons n'a pas été bien décrite. Au printemps et à l'été des années 2002 à 2004, nous avons échantillonné les migrations en aval des poissons du cours principal du fleuve Yukon, près de la frontière canado-américaine et ce, à l'aide d'un piège rotatif. Le saumon quinnat d'âge 0-juvénile, Oncorhynchus tshawytscha, était le poisson le plus souvent capturé, et son abondance était à son meilleur à la mi-juin. De plus petits nombres de saumon quinnat d'âge 1 et de saumon kéta d'âge $0, O$. keta, ont été attrapés au début de la saison. Plus de $80 \%$ du reste des poissons capturés consistait en des Coregoninae (ciscos) jeunes de l'année, qui étaient sans doute en voie de déplacement, passant de leur secteur natal aux habitats d'élevage d'été. Peu de ciscos adultes ont été capturés, probablement parce que notre échantillonnage a pris fin avant les migrations de reproduction d'automne. Des poissons juvéniles et adultes ont été attrapés dans le cas de six autres espèces de reproduction d'hiver ou de printemps que nous avons rencontrées. Nos résultats indiquent que le cours principal du fleuve Yukon sert énormément de corridor de migration. Dans cette partie du cours principal, les taux de sédiments en suspension sont très élevés l'été; son importance en tant qu'habitat d'élevage demeure inconnue. Des études plus poussées s'imposent dans le but de délimiter l'étendue des migrations et la structure de population des espèces non anadromes.

Mots clés : fleuve Yukon, migration, saumon quinnat, Oncorhynchus tshawytscha, saumon kéta, Oncorhynchus keta, cisco, Coregonus spp., Prosopium spp., inconnu, Stenodus leucichthys, lamproie arctique, Lampetra camtschatica, ombre arctique, Thymallus arcticus

Traduit pour la revue Arctic par Nicole Giguère.

\section{INTRODUCTION}

The life history of fishes in large rivers is often poorly understood. Galat and Zweimüller (2001:275) noted that the "lack of fundamental life-history information on most large-river fishes is perhaps the most serious impediment to understanding and managing assemblages of species that share common attributes." This is especially the case for the upper Yukon River, located in northwestern North America. Apart from the assessment of species caught in

\footnotetext{
${ }^{1}$ Fisheries and Oceans Canada and Cooperative Resource Management Institute, School of Resource and Environmental Management, Simon Fraser University, Burnaby, British Columbia V5A 1S6, Canada; mbradfor@ sfu.ca

${ }^{2}$ Community Stewardship Coordinator, Yukon Fish \& Wildlife Management Board, P.O. Box 844, Dawson City, Yukon Y0B 1G0, Canada

${ }^{3}$ Yukon River Commercial Fishing Association, Dawson City, Yukon Y0B 1G0, Canada; present address: 170 East 57th Avenue, Vancouver, British Columbia V5X 1S4, Canada

(C) The Arctic Institute of North America
} 
fisheries, fish biologists have devoted relatively little attention to the Yukon River, probably because of its remote location and the low levels of human disturbance within its catchment.

The Yukon River is the fourth largest drainage in North America, with a basin area of over $800000 \mathrm{~km}^{2}$. From its origins in northern British Columbia, it flows some $3200 \mathrm{~km}$ in a northwesterly arc through the Yukon Territory and Alaska to its mouth in the eastern Bering Sea (Fig. 1). The headwaters of the Yukon River consist of a series of large lakes, and consequently water clarity in the mainstem downstream of these lakes is relatively high. Farther downstream, however, glacial tributaries (most notably the White River) contribute considerable sediment to the mainstem, causing it to be very turbid during most of the open-water season (Brabets et al., 2000). While the channel is confined through much of its length, there is an extensive area of wetlands and floodplain channels called the Yukon Flats in central Alaska (Fig. 1). Ultimately the Yukon River discharges into the Bering Sea in a vast area of distributaries and wetlands in western Alaska.

At least 19 fish species occur in the upper Yukon River (defined as upstream of the western Yukon-Alaska border; Fig. 1) and its tributaries (Lindsay and McPhail, 1986). The most important, from a fisheries perspective, are the anadromous populations of chinook (Oncorhynchus tshawytscha) and chum (O. keta) salmon. These species are caught in commercial, subsistence, and aboriginal fisheries, mainly in Alaska. The main spawning areas for chum salmon are in the Yukon River and the White River and its tributaries. Spawner abundances have fluctuated between 22000 and 437000 fish since 1980 (JTC, 2006). Chinook salmon spawn in the Yukon River and most of its major tributaries and in a number of smaller streams. They are exclusively stream-type fish, with juveniles spending one or more years rearing in streams, rivers, or lakes before migrating to the ocean. Most leave the Yukon River as age- 1 smolts and return after spending 3-5 years at sea (Beacham et al., 1989). Spawner abundance in the upper basin has been estimated since 1982 and has ranged from 26000 to 81000 fish (P. Milligan, Fisheries and Oceans Canada, Whitehorse, Yukon, pers. comm. 2008).

Arctic grayling (Thymallus arcticus) is a popular sports fish in the upper Yukon basin, but little is known about its total abundance, spawning areas, or population structure. In addition, a variety of Coregoninae (whitefish) species can be locally important for sport and subsistence user groups (McPhail and Lindsey, 1970; Brown et al., 2007).

The focus of this study was to evaluate the downstream migrations of juvenile salmonids and other fishes in the upper Yukon River. Other than work on adult salmon (e.g., JTC, 2006), there has been only one study of fish migrations on the Yukon River, and it was qualitative in nature (Walker, 1976). This basic life history information is needed to help understand the factors that affect or limit productivity and potential harvest, to assess the impacts of human activities in the watershed on fish populations, and to understand the role of ongoing climate change on fisheries of northern North America.

\section{STUDY AREA AND METHODS}

Our sampling site was on the Yukon River $1 \mathrm{~km}$ upstream of Dawson City, Yukon, and $145 \mathrm{~km}$ upstream from the Canada-U.S. border (Fig. 1), which is approximately one-third of the distance between the headwaters and the mouth. The site is located more than $200 \mathrm{~km}$ downstream from the nearest significant chum and chinook salmon spawning areas in the basin.

At Dawson City, the Yukon River is ca. $500 \mathrm{~m}$ wide. Seasonal discharge patterns there are well approximated by the U.S. Geological Survey monitoring station (no. 15356000) located $160 \mathrm{~km}$ downstream at Eagle, Alaska. Judging by the difference in drainage area upstream of Dawson City compared to that upstream of Eagle, we conclude that the Eagle station likely overestimates discharge at Dawson City by less than $10 \%$. The average hydrologic regime is characterized by low flows from November to early May, increasing flow to mid-June, and a subsequent decline to winter baseflows (Brabets et al., 2000). The discharge regime results from a combination of lake discharge, snow and glacial melt, and summer rains and can vary considerably from one year to the next. The mean annual discharge (1950-2005) at Eagle is $2380 \mathrm{~m}^{3} / \mathrm{s}$, with average monthly extremes of $491 \mathrm{~m}^{3} / \mathrm{s}$ (March) and $6318 \mathrm{~m}^{3} / \mathrm{s}$ (June; USGS, 2007).

Suspended sediment concentrations at Eagle are very low $(1-2 \mathrm{mg} / \mathrm{L})$ in winter months, but they increase in the open-water season to averages of $450-650 \mathrm{mg} / \mathrm{L}$ in summer. Spot values in excess of $1500 \mathrm{mg} / \mathrm{L}$ have been recorded (Brabets et al., 2000). Most of the sediment load in our study area is from the White River, which drains glaciers of the St. Elias ranges in the southwestern part of the basin (Brabets et al., 2000) and enters the Yukon River $120 \mathrm{~km}$ upstream of Dawson City (Fig. 1).

We used a $2.4 \mathrm{~m}$ diameter floating rotary-screw trap (as described by Thedinga et al., 1994) to sample fish migrating downstream. We positioned the trap near the east bank of the river, using a pole-and-cable system that kept the centre line of the trap 4-5 $\mathrm{m}$ from the water's edge. The water depth at the trap location was about $3 \mathrm{~m}$, and the surface water velocity averaged $1.0 \mathrm{~m} / \mathrm{s}$. A projecting rock outcrop located $200 \mathrm{~m}$ upstream of the site deflected the current and most of the large debris away from the trap.

The trap was operated during the spring and summer of $2002-04$, although the start and duration of operations varied from year to year. The trap was usually fished continuously for five days and four nights each week, from Monday through Friday. Some exceptions occurred during periods of excessively high debris in the river, but these were relatively few.

The trap was checked 3-4 times daily, and each time the catch was removed from the livebox and the trap was 


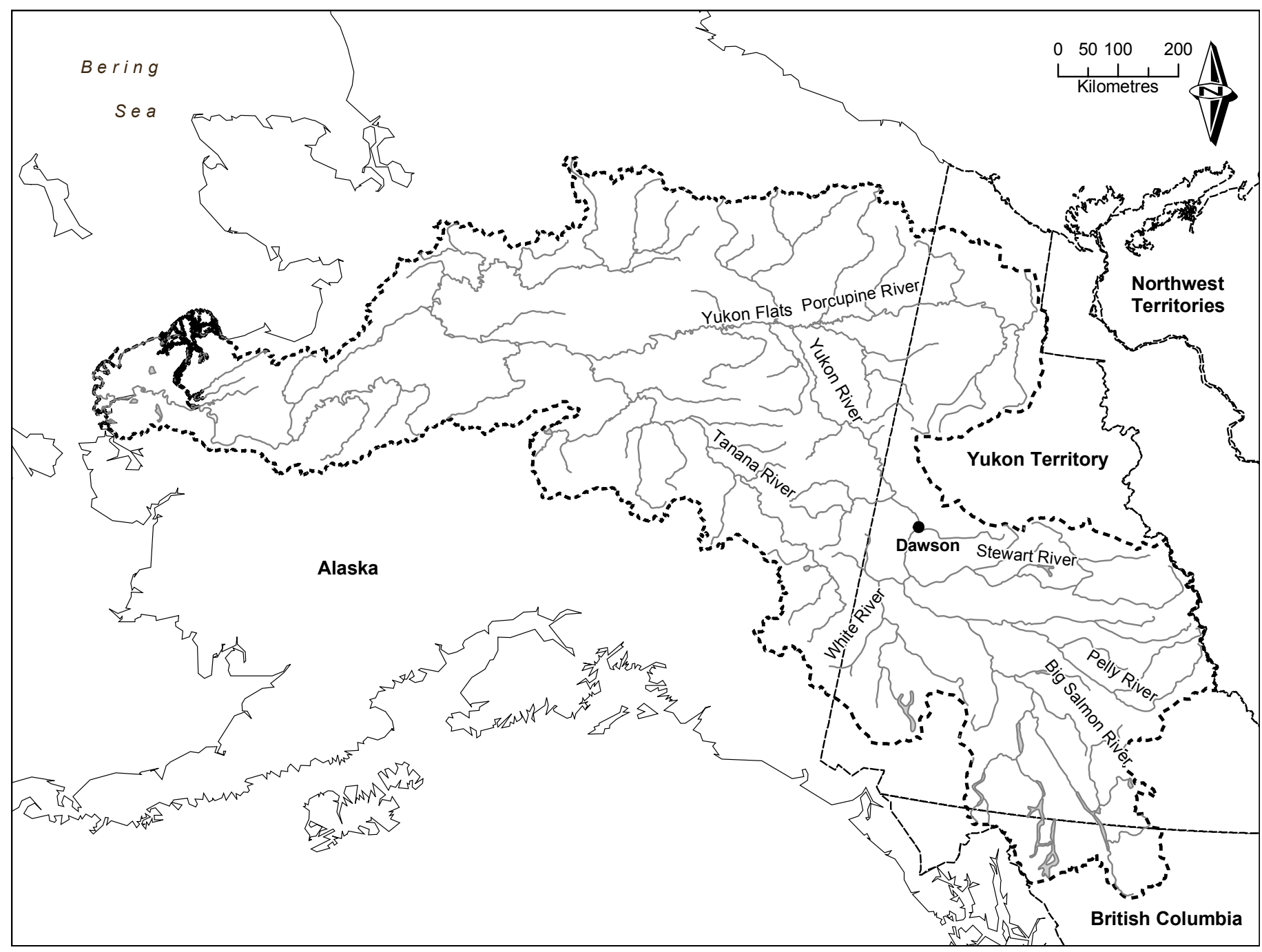

FIG. 1. Map of the Yukon River drainage basin, showing the major tributaries and the location of Dawson City, where our trap was located.

cleaned of debris with a brush or water pump. Fish were kept in aerated buckets for processing on board the attendant boat. They were anaesthetized in small groups with clove oil, identified, measured $(\mathrm{mm})$ for fork or total length (for species without forked caudal fins), and weighed to the nearest $0.1 \mathrm{~g}$. After recovery, fish were released back into the river. River water temperature at the sampling site was measured hourly with a data logger.

The identification of juvenile Coregoninae in the field is especially challenging, and although we attempted to identify each fish to species, our identifications have not been confirmed by morphological or genetic analysis. In addition, taxonomic uncertainty exists regarding the lake/ humpback whitefish complex (Coregonus clupeaformis, C. pidschian, and C. nelsonii), so following the likely distributions (McPhail and Lindsay, 1970), we used C. clupeaformis in this report. For the purposes of summarizing catch and size information, we grouped the whitefish as: Stenodus (inconnu, S. leucichthys), Coregonus (C. clupeaformis, C. nasus, C. sardinella), and Prosopium (P. cylindraceum). Bering cisco (C. laurettae) and pygmy whitefish (P. coulteri) are present in the Yukon basin but have not been confirmed in our study area, and it is unknown whether they were present in our catches.

Catch rates were calculated as the number of fish per hour of trap operation, averaged by week. The age of juvenile chinook salmon (as either age- 0 or age- 1 or older migrants) was inferred by examining length frequency data weekly or monthly and assigning a length cutoff for each age class by time period. The lengths of the other species were used to classify fish as either young-of-theyear, juveniles, or adults based on observations or size-age relations developed for other populations in the Yukon, Alaska, and Russia (Berg, 1948; McPhail and Lindsey, 1970; Alt, 1973a, b, 1979; Steigenberger and Elson, 1977; Shestakov, 2001).

\section{RESULTS}

Yukon River discharge at Eagle, Alaska, was below average in 2002 and 2003 and above average in 2004, 

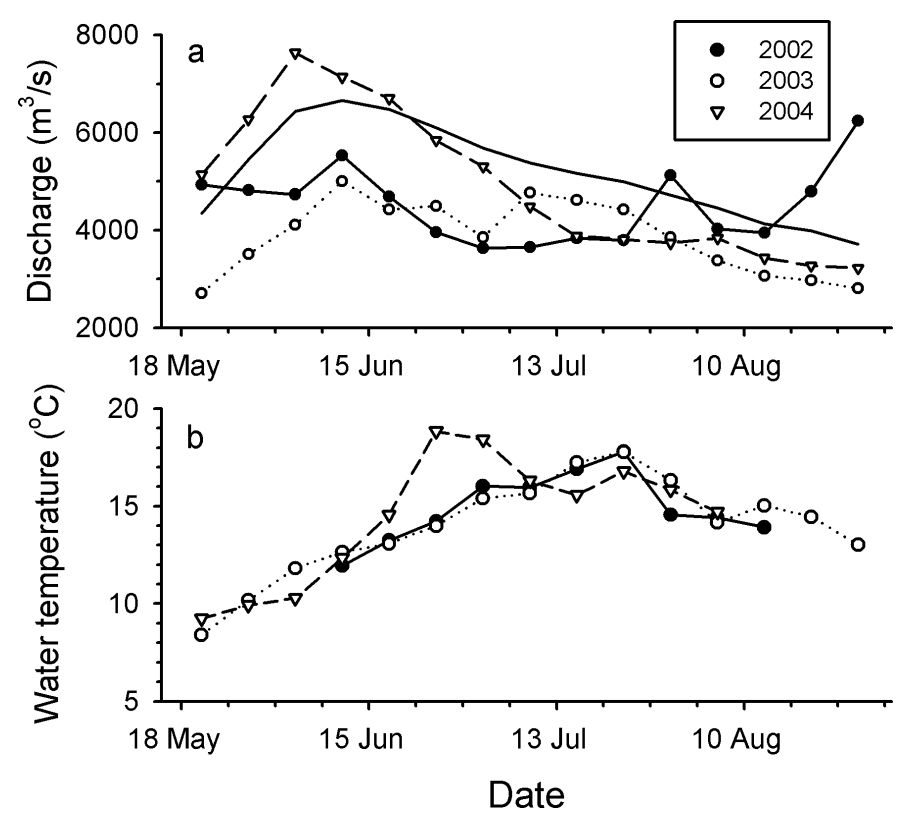

FIG. 2. a: Mean weekly discharge in the Yukon River at Eagle, Alaska, in 2002 (-), $2003(\bigcirc)$ and $2004(\nabla)$. The solid line without symbols is the long-term average discharge. b: Mean weekly water temperature of the Yukon River at Dawson City, 2002-04 (symbols as above).

when the peak discharge was $50 \%$ greater than in the first two study years (Fig. 2). River water temperatures increased through May and June, and peaked in late June 2004, and in late July in the other years (Fig. 2). The maximum hourly temperatures $\left({ }^{\circ} \mathrm{C}\right)$ recorded by year were 18.3 for $2002,18.5$ for 2003 , and 18.7 for 2004 .

\section{Salmon}

Catches of age- 0 chinook salmon were low in May, but increased to a peak in late June in all years (Fig. 3). In 2003, when the program continued to the end of August, there were small catches during each week throughout July and August. The total catches in 2002, 2003, and 2004 were 1515,1060 , and 5487 fish, respectively. The corresponding parent escapements for these broods were 52564, 42359, and 80594 fish.

Catches of age- 1 and older juvenile chinook salmon were highest at the beginning of the sampling program, and the migration was largely completed by late June (Fig. 3). Far fewer yearlings were caught than age- 0 salmon; the total catches by year were 68,109 , and 226 individuals.

The downstream migration of age- 0 chum salmon appeared to peak earlier than that of age- 0 chinook salmon; it was already underway when our trap was first installed in late May (Fig. 3). Catches declined through June, and the migration was complete by early July. The annual catches of chum salmon fry were 159, 268, and 599 for the three years of sampling. The corresponding parent escapements were 33851 fish for 2002, 98695 for 2003, and 142683 for 2004 (JTC, 2006).

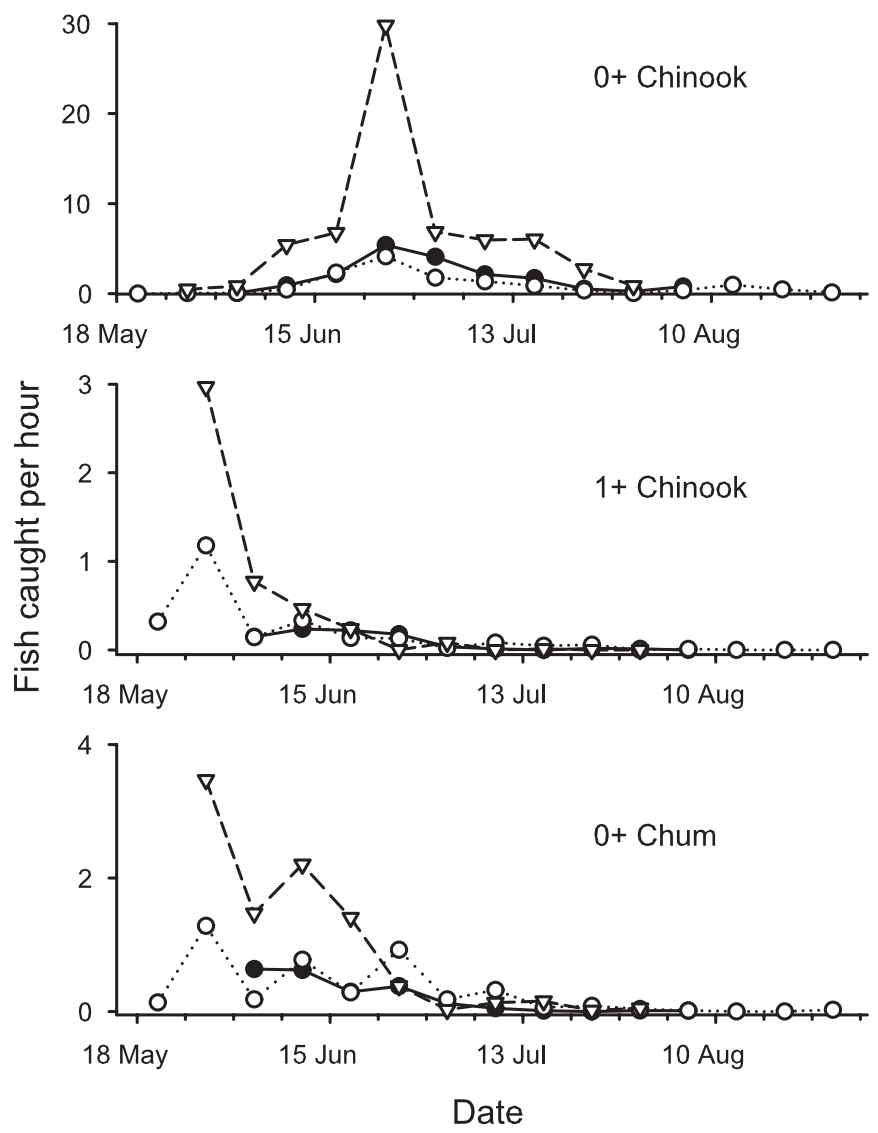

FIG. 3. The number of juvenile salmon caught per hour of trap operation for age- 0 and age- 1 and older juvenile chinook salmon and age- 0 chum salmon, 2002-04. Weekly averages are shown. Symbols as in Figure 2.

Size of age- 0 and age- 1 chinook salmon increased steadily during the sampling season, but there were few consistent differences among years in the size at a given date (Fig. 4). For May and June, the average rate of increase in length was $0.68 \mathrm{~mm} /$ day for age-0 fish and $0.36 \mathrm{~mm} /$ day for age- 1 juveniles. The rate of increase in age-0 length declined in July and August to an average of $0.36 \mathrm{~mm} /$ day. Too few age- 1 juveniles were caught during this period for a meaningful estimate. At the peak of migration, on average, age- 0 chinook salmon were $52 \mathrm{~mm}$ in length and weighed $1.5 \mathrm{~g}$, while age- 1 chinook salmon were $84 \mathrm{~mm}$ long and weighed $6.1 \mathrm{~g}$.

The mean length of chum salmon declined over the duration of the migration, and those caught in July were on average $3 \mathrm{~mm}$ shorter than those caught in May (Fig. 4). At the peak of migration, the average size was $38.8 \mathrm{~mm}$ and $0.45 \mathrm{~g}$.

\section{Arctic Grayling}

To simplify the presentation, the catches of Arctic grayling were summed across years. Three different size classes were captured. Before June 1, adults (>250 mm) were common, along with juveniles $60-100 \mathrm{~mm}$ in length (suspected age-1; Fig. 5). The juveniles continued to be caught in June and early July, but adult catches nearly 


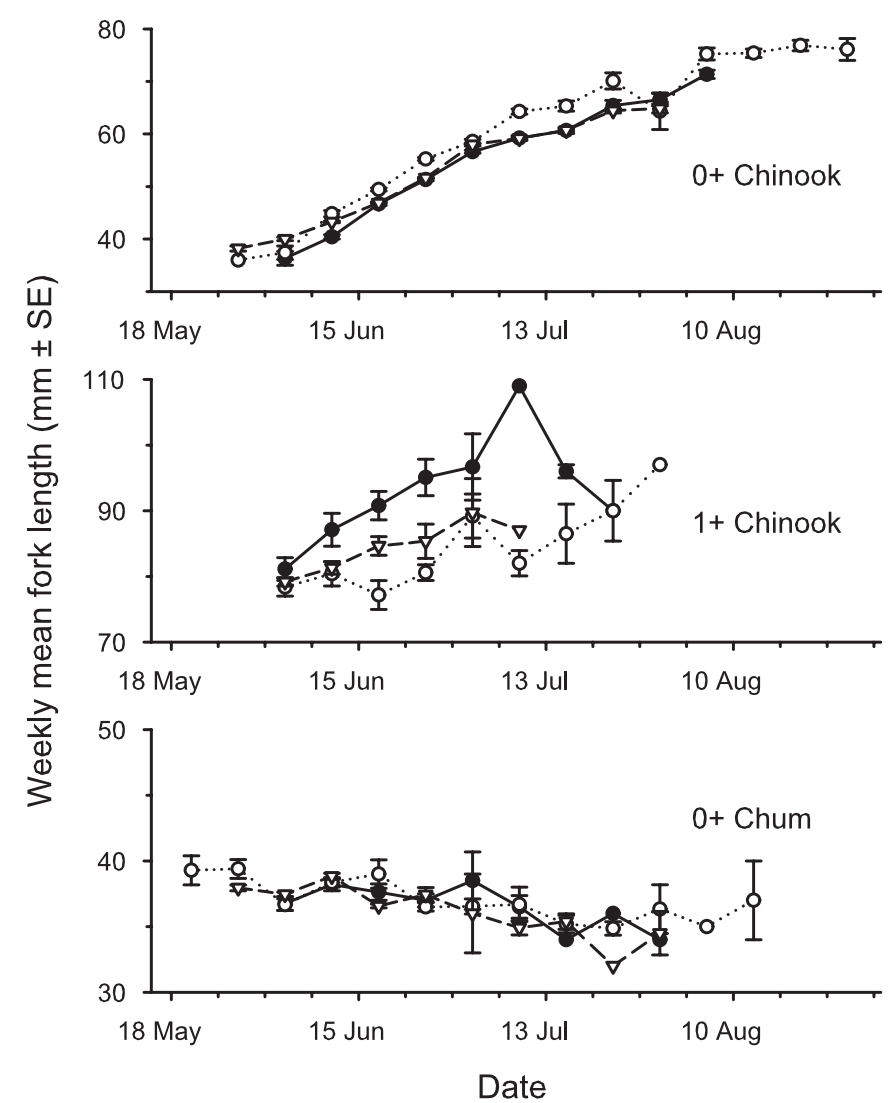

FIG. 4. Weekly mean fork length ( \pm standard error) of juvenile salmon caught in the downstream trap, 2002-04. Symbols as in Figure 2.

ceased during this time period. Later in July a large mode of smaller juveniles that were $20-60 \mathrm{~mm}$ in length formed the bulk of the catch; these were likely age- 0 fish resulting from spawning that occurred earlier in the spring. Larger grayling were uncommon after mid-July (Fig. 5).

\section{Coregoninae}

Members of the fall-spawning Coregoninae subfamily were very common in our catches (Table 1). A few adult whitefish were captured, but the catch was dominated by age0 ( $<100 \mathrm{~mm}$ length) juveniles (Fig. 6). The modal length of juvenile inconnu was greater than that of the other species groups; however, this species is noted for fast growth relative to other whitefish (Steigenberger and Elson, 1977). There was no pronounced seasonal peak in the timing of the downstream migration of juvenile whitefish (Fig. 7), as the catch rates varied among species groups, and also among years.

\section{Other Species}

We combined the three years of data to provide a more concise account of the catches of the other six species we caught. These species are spring spawners, with the exception of burbot Lota lota, which spawns in late winter. Both juvenile and adults were caught (Fig. 8). Arctic lamprey Lampetra camtschatica, longnose suckers Catostomus

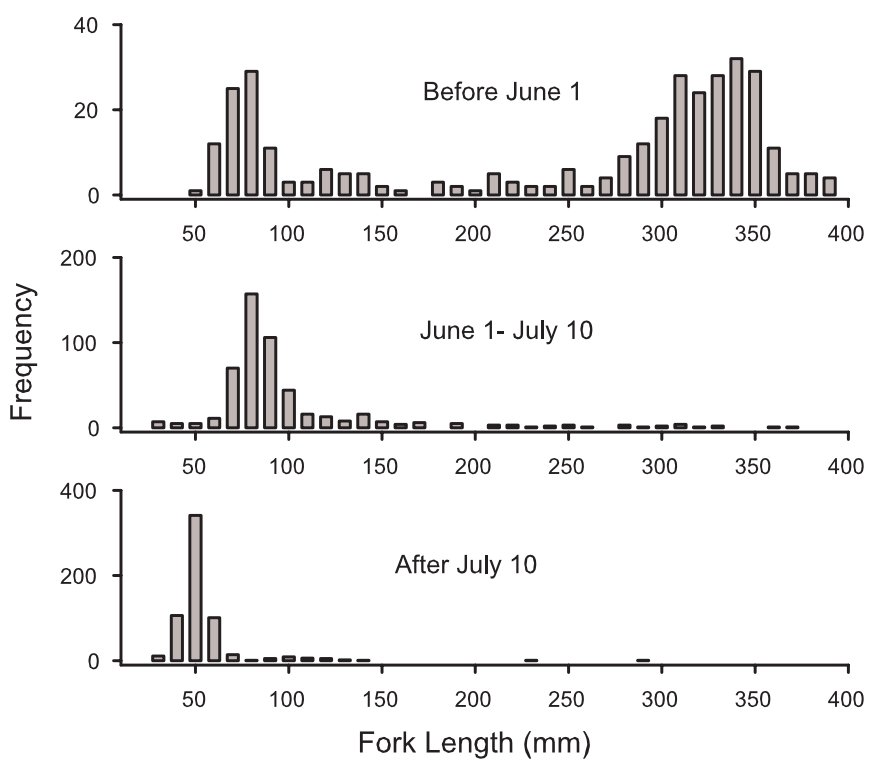

FIG. 5. Histograms of fork lengths of arctic grayling captured in the downstream trap by three time periods, 2002-04, all years combined.

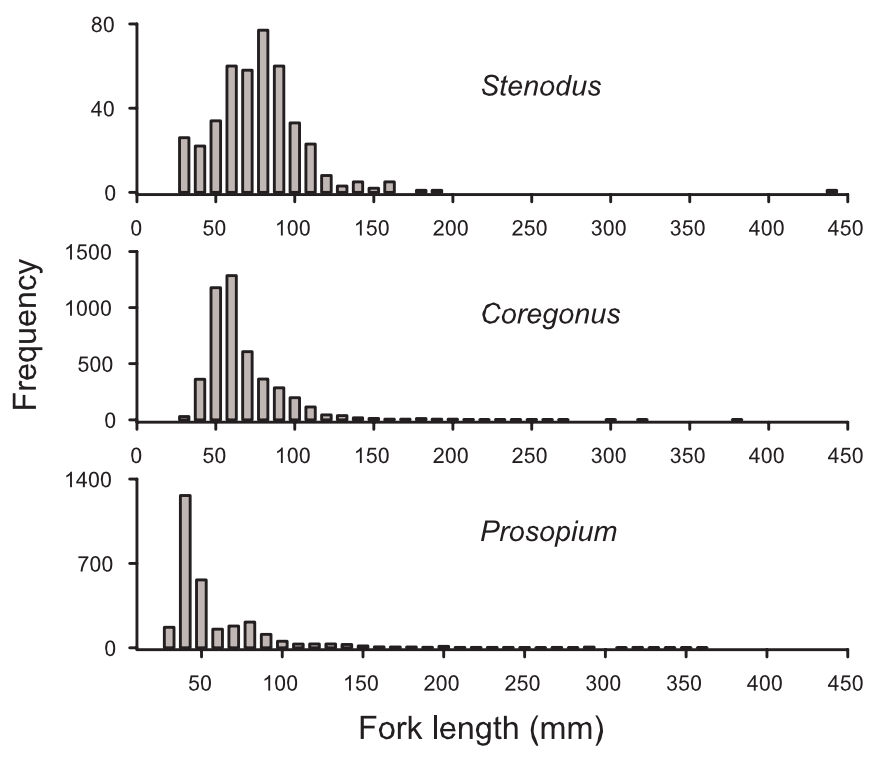

FIG. 6. Histograms of fork lengths of three genera of Coregoninae captured in the downstream trap, 2002-04.

catostomus, and lake chub Couesius plumbeus were the most common in the catches (Table 1). Lamprey catches tended to peak early in the sampling period, but there was no consistent temporal pattern for the other five species.

\section{DISCUSSION}

Although the segment of the Yukon River that we sampled might be viewed as a relatively inhospitable environment for fishes during the open-water season because of its high levels of suspended sediment, our results show that it remains important migratory habitat for many species. Sampling habitats along the margins of 
TABLE 1. Annual catches of fish in the downstream trap at Dawson City, Yukon. Last row are small $(<50 \mathrm{~mm}$ FL) whitefish juveniles that were not identified. The decreasing trend partly reflects increasing attempts by field crews in identifying juveniles to genus.

\begin{tabular}{|c|c|c|c|c|}
\hline Species & & 2002 & 2003 & 2004 \\
\hline Arctic Grayling & Thymallus arcticus & 585 & 646 & 478 \\
\hline Arctic Lamprey & Lampetra camtschatica & 18 & 79 & 71 \\
\hline Burbot & Lota lota & 7 & 28 & 12 \\
\hline Chinook Salmon & Oncorhynchus tshawytscha & 1583 & 1169 & 5713 \\
\hline Chum Salmon & O. keta & 159 & 268 & 599 \\
\hline Coregonus spp. & C. clupeaformis, $C$. nasus, C. sardinella & 2120 & 978 & 1725 \\
\hline Inconnu & Stenodus leucichthys & 264 & 88 & 80 \\
\hline Lake Chub & Couesius plumbeus & 60 & 69 & 36 \\
\hline Longnose Sucker & Catostomus catostomus & 499 & 364 & 301 \\
\hline Northern Pike & Esox lucius & 16 & 3 & 8 \\
\hline Round Whitefish & Prosopium cylindraceum & 1751 & 738 & 484 \\
\hline Slimy Sculpin & Cottus cognatus & 6 & 10 & 9 \\
\hline Unidentified Coregoninae & & 2107 & 648 & 365 \\
\hline
\end{tabular}

the Yukon River near Dawson generally yield few fish, except at the confluences of clearwater tributaries (Bradford et al,. unpubl. data). A similar pattern was observed in the turbid Taku (Murphy et al., 1989) and Tanana (Durst, 2001) rivers in Alaska. In those studies, summer fish densities were higher in less turbid off-channel habitats than in the mainstem. Our results appear consistent with the flood-pulse concept of Junk et al. (1989), who proposed that large river mainstems were primarily migration corridors that connected more productive off-channel areas and tributaries located within the floodplain. However, a structured sampling program has not yet been conducted on the turbid portions of the Yukon River mainstem, and its significance as important habitat for some species or life stages cannot be ruled out.

\section{Salmon}

Chinook salmon show considerable variation in their freshwater life history both within and across populations (Healey, 1991). Juveniles emerge from spawning gravels in late May (Walker, 1976), and although newly emerged fry can travel considerable distances after emergence (Bradford and Taylor, 1997), we caught relatively few fish that were under $40 \mathrm{~mm}$ in length (the size at emergence) in our trap. The migrants we caught were $45-60 \mathrm{~mm}$ in length and had likely reared for four to six weeks at upstream locations before passing the trap site. Bradford et al. (2001) noted that age-0 chinook salmon from the Yukon River mainstem colonized a non-natal stream in the upper Yukon basin in late June. Thus it appears that, after an initial period of rearing that presumably occurs closer to their natal areas, there is a large-scale downstream redistribution of juveniles in the Yukon River in June. The timing of the migration of age- $1+$ juveniles is consistent with results from other rivers (Healey, 1991), although the distance $(>2000 \mathrm{~km})$ that these fish travel before reaching the ocean likely entails a midsummer ocean entry.

The size and timing of juvenile chum salmon in our catches suggest that they are migrating directly from spawning areas towards the ocean, like the chum salmon in coastal streams, where the migration distances are much shorter (Salo, 1991). The migration appeared to be well underway when our sampling program started in late May, indicating the peak may have occurred a few weeks earlier. This is slightly later than the timing of fry migration in the Taku River (Meehan and Siniff, 1962) and in the Chena River, a tributary of the Yukon River in central Alaska (Peterson, 1997). Martin et al. (1986) also found that chum salmon were most common in the Yukon River Delta in June and early July, and the modal size was also $30-40 \mathrm{~mm}$. Although juveniles caught in the lower Yukon River could be from a large number of populations, the size and timing of those catches are consistent with the direct migration strategy that we observed for the upper river.

We found a consistent, and somewhat unusual, pattern of a decrease in the mean size of chum salmon fry during the course of the migration. In the Fraser River, Beacham and Starr (1982) noted an increase in size during the migration that they attributed to freshwater rearing and growth for those fish migrating after the main peak. The decrease we observed may have been due to a change in the composition of the run over the season and populationspecific differences in fry size. Or, fish migrating later in the season may have been poorer in quality, in terms of their timing and size at emergence and their rate of downstream migration in the river.

Index sampling of juvenile salmonids can be used to provide information for stock assessment purposes (Todd, 1966; Niemelä et al., 2005). In the case of chum salmon, we did find a parallel trend on both parent spawner abundance and total fry catch over the three years that suggests some coherence between the two measures of abundance. However, the relatively small number of fry captured relative to the size of the spawning populations highlights that our trap was capturing only a very small fraction of the total migration, which will likely limit its utility for indexing adult abundance.

For chinook salmon, utility of indexing downstream migrations of juveniles is less clear because their life history is more complex, and both within and among populations 


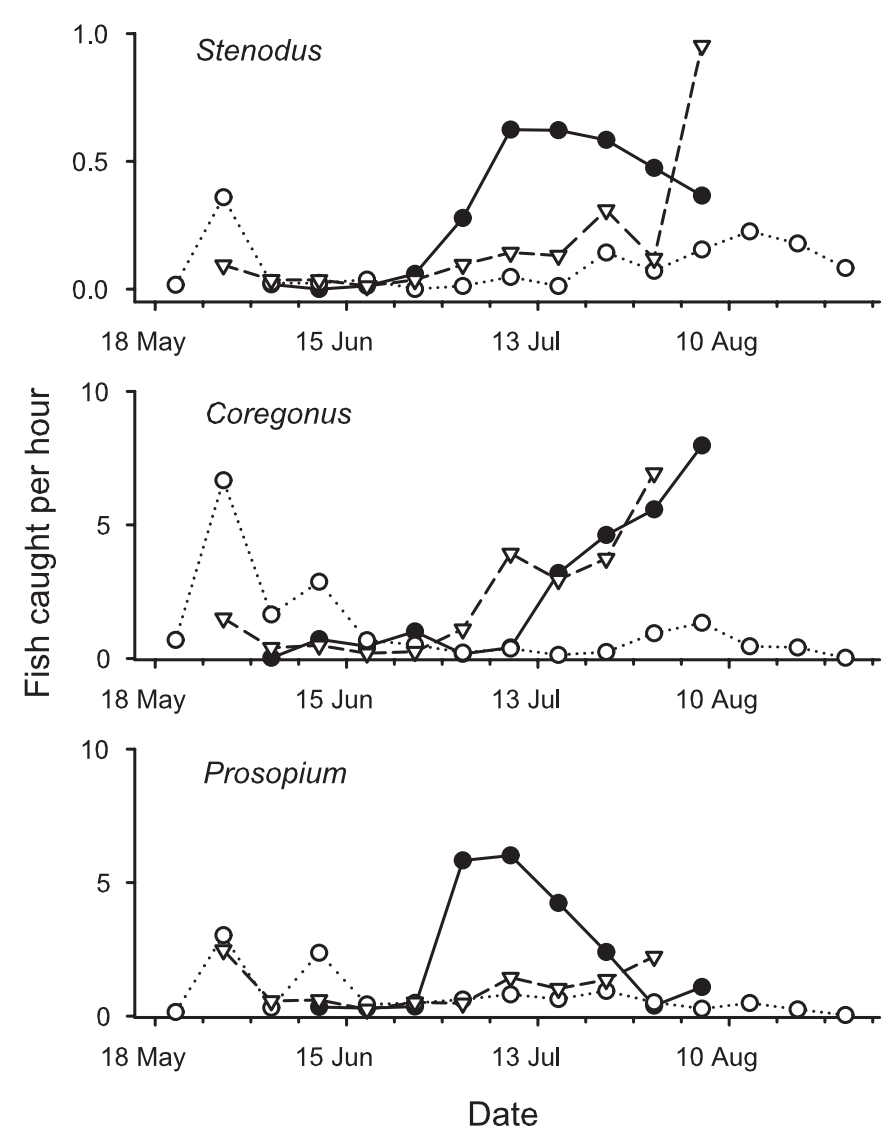

FIG. 7. The number of Coregoninae caught per hour of trap operation, 2002-04. Weekly averages are shown. Symbols as in Figure 2.

there can be individuals that migrate great distances in freshwater, and others that remain close to their natal areas (Bradford and Taylor, 1997). Thus the number of age-0 and age-1 migrants will be a function of parent abundance, variation in survival, and variation in the migratory behaviour both within and between populations. Our observation that both the total juvenile catch and the Yukon River discharge were much greater in 2004 than in the other two years raises the possibility that higher flows may affect migratory propensity. So few age-1 juveniles were caught that the catches of this life stage are unlikely to be useful for forecasting future adult abundances.

\section{Arctic Grayling}

For arctic grayling, Northcote (1995:156) notes that populations "undergo a complex cycle of migratory behaviour," and our trapping results provide an indication of this for the upper Yukon River. Our early-season catches were characterized by large numbers of adult fish, likely moving downstream from spawning areas. Grayling spawn soon after the ice melts in May, and adults leave tributary spawning areas and travel to summer feeding areas soon after reproduction (Northcote, 1995). The May to mid-July period was characterized by large catches of age- 1 and older juveniles moving downstream, presumably from overwintering

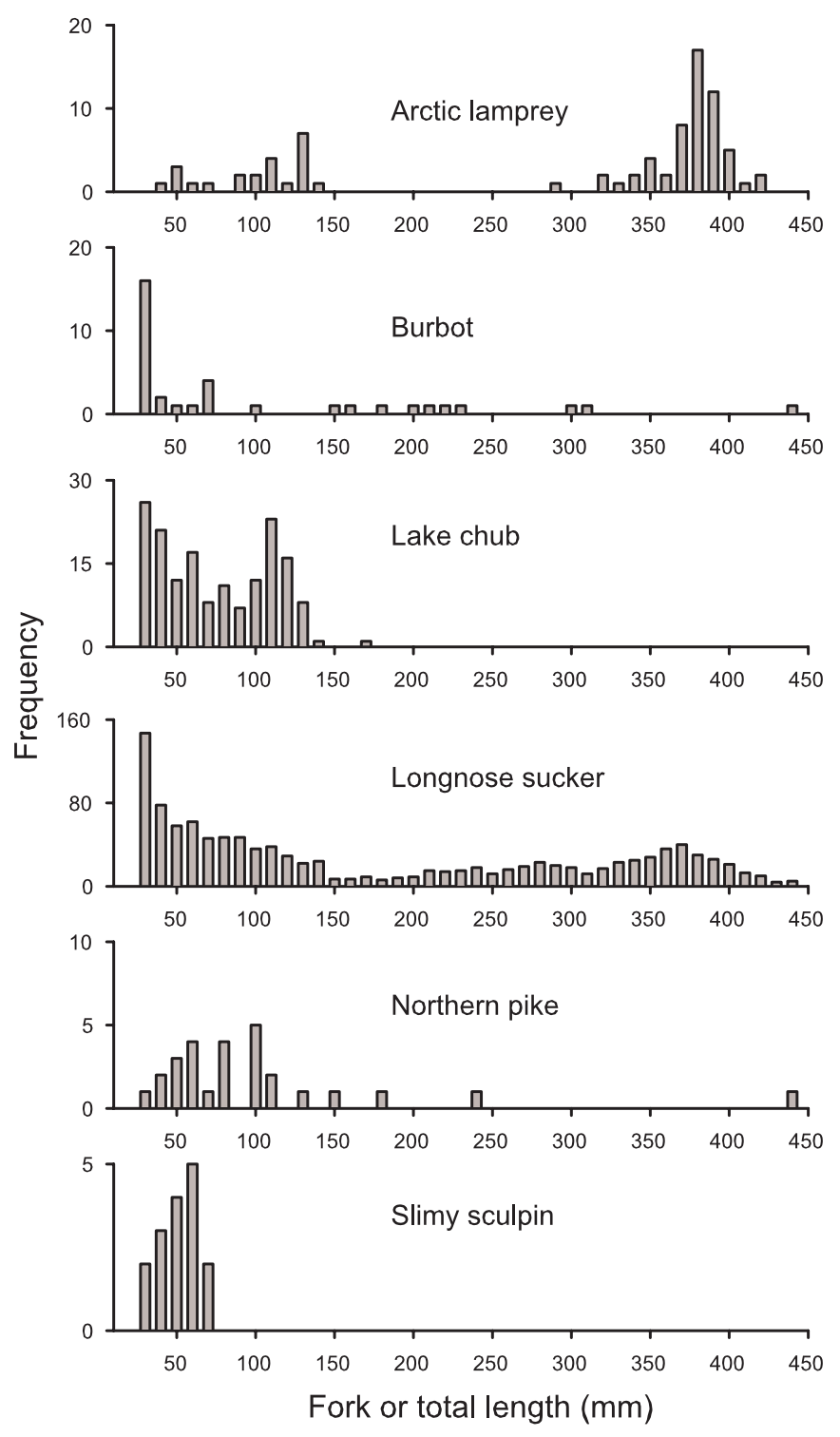

FIG. 8. Histograms of fork or total lengths of six other species captured in the downstream trap, combined over three years of sampling, 2002-04.

to summer feeding areas. The absence of age- 1 or older grayling in catches after early July indicates the end of these migrations. The last migration we sampled was that of age- 0 fish presumed to be moving from spawning streams to rearing areas. Arctic grayling fry have also been observed to leave spawning streams in late June and early July in the Mackenzie River basin (Jessop et al., 1974; Butcher et al., 1981). The distance these juveniles travel and the location of their summer rearing areas are unknown.

\section{Coregoninae}

The catch of the fall-spawning whitefish species was dominated by age- 0 and lesser numbers of age- 1 juveniles. Most adult whitefish move upstream to spawning areas in late summer and fall, and migrate downstream to overwintering areas or the ocean after spawning in the late 
fall (Stein et al., 1973; Alt, 1973b, 1977, 1979; Shestakov, 2001). Shestakov (2001) noted that adult broad whitefish used floodplain lakes and off-channel areas for summer rearing before their upstream migration to spawning areas. A similar behaviour may occur in the Yukon River, with the extensive floodplain waterways of the Yukon Flats in central Alaska serving as a summer rearing area (Alt, 1979). Adult whitefish have been captured in the spring and summer in the less turbid reaches of the upper Yukon near Minto (Walker, 1976) and in the Porcupine River, a major tributary of the Yukon River (Steigenberger and Elson, 1977), which is also much less turbid than the Yukon River mainstem at our study site. Thus turbidity may also play a role in determining the suitability of the mainstem as spring and summer habitat for feeding by adult whitefish.

The large numbers of age- 0 whitefish in our catches suggest a very significant downstream migration of young fish. In Russia, larval whitefish ( $<15 \mathrm{~mm}$ length) emerge and migrate from spawning streams in late May (Shestakov, 1991). Shestakov (1992) found large numbers of juveniles in side-channels and lakes of the Anadyr River floodplain in early summer. Reist and Bond (1988) also note the use of floodplain lakes as summer rearing areas in the Mackenzie River. The whitefish we captured had grown 30-40 $\mathrm{mm}$ since hatching, indicating rearing at an upstream location before their migration past our trap site. The recent results from Brown et al. (2007) suggest that it is unlikely that these fish are anadromous, but they may be moving to off-channel habitats such as those of the Yukon Flats region.

Inferences about whitefish are hampered by difficulties in identifying juveniles using external characteristics in the field. In the case of the Bering cisco, the apparent rarity of the species in Canadian waters has led to its being designated as one of "special concern" by the Committee on the Status of Endangered Wildlife in Canada (COSEWIC, 2004). This designation might be revised if a significant number of Bering cisco were among the ciscoes in our samples. Molecular markers will likely be required to confirm the identification of juvenile whitefish.

\section{Other Species}

The variety of life stages of the winter- and springspawning species migrating downstream in the Yukon River in early summer reflects both the significance of the mainstem as a migration corridor and the diversity of life histories within the Yukon River fish communities.

Arctic lampreys have occasionally been sighted in the upper Yukon basin, but little is known of their ecology. Anadromous adults migrate upstream from the ocean in the fall and overwinter in freshwater before spawning in tributary streams in the spring. Adults die after spawning. Our trap captured a significant number of large adult lampreys, perhaps because of a downstream movement of spawned-out anadromous fish similar to that observed in the John Day River in Oregon for L. tridentate (Robinson and Bayer, 2005). Anadromous adult lampreys were captured only between 9 and 30 June, a timing similar to that of lampreys that Heard (1966) captured in the Naknek River, Alaska. The juveniles that we captured appeared to be a mixture of smaller, younger fish that were likely moving among habitats, and larger $(>100 \mathrm{~mm})$ ammocytes that may have been migrating to the ocean. Nonanadromous forms also occur in this species (Heard, 1966; McPhail and Lindsey, 1970), but their presence in the upper basin is unknown.

We caught significant numbers of adult-sized fish of the other spring-spawning species. The capture of these adults is consistent with previous observations that these species can tolerate high turbidity levels and have been observed to make use of mainstem river habitats during the summer months. Bresser et al. (1988) used telemetry information to infer that burbot used the mainstem Tanana River, a large glacial tributary of the Yukon River. It is possible that our captures in the Yukon mainstem may represent localized movements to specific feeding areas, such as tributary creek mouths. Longnose sucker, lake chub, and to a lesser extent slimy sculpin, are relatively common in shoreline sampling of mainstem habitats in the less turbid reaches of the upper Yukon River (Walker, 1976) and in the Porcupine and Tanana rivers, both large tributaries of the Yukon (Steigenberger and Elson, 1977; Durst, 2001). Our catches of juveniles and adults of these species may also be the result of local movements rather than migrations.

Age-0 fish were also common in our catches of the spring spawning species. A downstream migration of age0 longnose suckers from tributary spawning streams in June and July was observed in the Mackenzie River basin (Jessop et al., 1974), and similar behaviours are likely for other spring spawning species as they redistribute from spawning to summer rearing areas.

In conclusion, our results provide a small piece of the information required for a fuller understanding of the life history and habitat use of fishes of the Yukon River and its tributaries. In addition to our migration study, a systematic sampling program of a variety of habitats in both the main channel and the floodplain is required to evaluate the role of the turbid mainstem as a fish-producing region. Habitat use studies and a combination of tagging and telemetry studies, as well as the use of geochemical and genetic markers, may be required to fully understand the scale of migrations and population structure for these species. Although many of the species we sampled are found throughout the basin, individual populations may have fidelity to specific habitats at various points in their life cycle and therefore may be affected by habitat impacts in those areas. The vast scale of the landscape and the logistical difficulties of working in this region will continue to present considerable challenges to those attempting to develop a fuller understanding of the fish fauna of the Yukon River. 


\section{ACKNOWLEDGEMENTS}

This project was funded by the Yukon River Restoration and Enhancement Fund, administered by the Yukon River Panel of the Pacific Salmon Commission. Thanks to Pat Milligan and Al von Finster of Fisheries and Oceans Canada, Whitehorse, for project oversight and assistance; to Nick de Graff and Paul Sparling, for their help with species identification; and to Daniel Hirner, for producing Figure 1. Fieldwork was carried out with the capable assistance of David Curtis, Jonathan Howe, and R.J. Nagano. Randy J. Brown and David Daum of the U.S. Fish and Wildlife Service and two anonymous reviewers provided comments on a draft manuscript.

\section{REFERENCES}

ALT, K.T. 1973a. Age and growth of the inconnu (Stenodus leucichthys) in Alaska. Journal of the Fisheries Research Board of Canada 30:457-459.

.1973b. Contributions to the biology of the Bering cisco

(Coregonus laurettae) in Alaska. Journal of the Fisheries Research Board of Canada 30:1885-1888.

- 1977. Inconnu, Stenodus leucichthys, migration studies in Alaska 1961-1974. Journal of the Fisheries Research Board of Canada 34:129-133.

1979. Contributions to the life history of the humpback whitefish in Alaska. Transactions of the American Fisheries Society 108:156-160.

BEACHAM, T.D., and STARR, P. 1982. Population biology of chum salmon, Oncorhynchus keta, from the Fraser River, British Columbia. Canadian Journal of Fisheries and Aquatic Sciences 43:244-261.

BEACHAM, T.D., MURRAY, C.B., and WITHLER, R.E. 1989. Age, morphology, and biochemical genetic variation of Yukon River chinook salmon. Transactions of the American Fisheries Society 118:46-63.

BERG, L.S. 1948. Freshwater fishes of the U.S.S.R. and adjacent countries, Vol. 1. Academy of Sciences of the U.S.S.R. Jerusalem: Israel Program for Scientific Translations, 1962. $493 \mathrm{p}$.

BRABETS, T.P., WANG, B., and MEADE, R.H. 2000. Environmental and hydrologic overview of the Yukon River basin, Alaska and Canada. United States Geological Survey Water-Resources Investigations Report 99-4204. 106 p.

BRADFORD, M.J., and TAYLOR, G.C. 1997. Individual variation in dispersal behaviour of newly emerged chinook salmon from the upper Fraser River, British Columbia. Canadian Journal of Fisheries and Aquatic Sciences 54:1585-1592.

BRADFORD, M.J., GROUT, J.A., and MOODIE, S. 2001. Ecology of juvenile chinook salmon in a small non-natal stream of the Yukon River drainage and the role of ice conditions on their distribution and survival. Canadian Journal of Zoology 79: 2043-2054.

BRESSER, S.W., STEARNS, F.D., SMITH, M.W., WEST, R.L., and REYNOLDS, J.B. 1988. Observations of movements and habitat preferences of burbot in an Alaskan glacial river system. Transactions of the American Fisheries Society 117:506-509.
BROWN, R.J., BICKFORD, N., and SEVERIN, K. 2007. Otolith trace element chemistry as an indicator of anadromy in Yukon River drainage coregonid fishes. Transactions of the American Fisheries Society 136:678-690.

BUTCHER, G.A., ELLIS, J.R., and DAVIDSON, R.B. 1981. Aspects of the life history of arctic grayling in the Liard River drainage, British Columbia. British Columbia Ministry of Environment Working Paper 1981-04. 39 p.

COSEWIC (COMMITTEE ON THE STATUS OF ENDANGERED WILDLIFE IN CANADA). 2004. COSEWIC assessment and update status report on the Bering cisco Coregonus laurettae in Canada. Ottawa: COSEWIC. 19 p.

DURST, J.D. 2001. Fish habitats and use in the Tanana River floodplain near Big Delta, Alaska, 1999-2000. Alaska Department of Fish and Game Technical Report 01-05. 55 p.

GALAT, D.L., and ZWEIMÜLLER, I. 2001. Conserving largeriver fishes: Is the highway analogy an appropriate paradigm? Journal of the North American Benthological Society 20: 266-279.

HEALEY, M.C. 1991. Life history of chinook salmon. In: Groot, C., and Margolis, L., eds. Pacific salmon life histories. Vancouver: UBC Press. 311-394.

HEARD, W.R. 1966. Observations on lampreys in the Naknek River system of southwest Alaska. Copeia 1966:332-339.

JESSOP, C.S., CHANG-KUE, K.T.J., LILLY, J.W., and PERCY, R.J. 1974. A further evaluation of the fish resources of the Mackenzie River valley as related to pipeline development. Task Force on Northern Oil Development, Report 74-7. 95 p.

JTC (JOINT TECHNICAL COMMITTEE OF THE YUKON RIVER US/CANADA PANEL). 2006. Yukon River salmon 2005 season summary and 2006 season outlook. Regional Information Report No3A06-03. Anchorage: Alaska Department of Fish and Game, Division of Commercial Fisheries. 25 p.

JUNK, W.J., BAYLEY, P.B., and SPARKS, R.E. 1989. The flood pulse concept in large river-floodplain systems. In: Dodge, D.P., ed. Proceedings of the International Large River Symposium. Canadian Special Publications of Fisheries and Aquatic Sciences 106. $110-127$.

LINDSEY, C.C., and McPHAIL, J.D. 1986. Zoogeography of fishes of the Yukon and Mackenzie basins. In: Hocutt, C.H., and Wiley, E.O., eds. The zoogeography of North American freshwater fishes. New York: John Wiley \& Sons. 639-674.

MARTIN, D.J., GLASS, D.R., WHITMUS, C.J., SIMENSTAD, C.A., MILWARD, D.A., VOLK, E.C., STEVENSON, M.L., NUNES, P., SAVOIE, M., and GROTEFENDT, R.A. 1986. Distribution, seasonal abundance, and feeding dependencies of juvenile salmon and non-salmonid fishes in the Yukon River Delta. NOAA OCSEAP Final Report 55. 381-770.

McPHAIL, J.D., and LINDSAY, C.C. 1970. Freshwater fishes of northwestern Canada and Alaska. Fisheries Research Board of Canada Bulletin 173. 381 p.

MEEHAN, W.R., and SINIFF, D.B. 1962. A study of the downstream migrations of anadromous fishes in the Taku River, Alaska. Transactions of the American Fisheries Society 91:399-407.

MURPHY, M.L., HEIFETZ, J., THEDINGA, J.F., JOHNSON, S.W., and KOSKI, K.V. 1989. Habitat utilization by juvenile Pacific salmon (Oncorhynchus) in the glacial Taku River, 
southeast Alaska. Canadian Journal of Fisheries and Aquatic Sciences 46:1677-1685.

NIEMELÄ, E., ERKINARO, J., JULKUNEN, M., and HASSINEN, E. 2005. Is juvenile salmon abundance related to subsequent and preceding catches? Perspectives from a long-term monitoring programme. International Council for the Exploration of the Sea (ICES) Journal of Marine Science 62:1617-1629.

NORTHCOTE, T.G. 1995. Comparative biology and management of Arctic and European grayling (Salmonidae, Thymallus). Reviews in Fish Biology and Fisheries 5:141-194.

PETERSON, B.D. 1997. Estimation of abundance and mortality of emigrating chum salmon and chinook salmon in the Chena River, Alaska. MS thesis, University of Alaska Fairbanks. $108 \mathrm{p}$.

REIST, J.D., and BOND, W.A. 1988. Life history characteristics of migratory coregonids of the lower Mackenzie River, Northwest Territories, Canada. Finnish Fisheries Research 9:133-144.

ROBINSON, T.C., and BAYER, J.M. 2005. Upstream migration of Pacific lampreys in the John Day River, Oregon: Behavior, timing, and habitat use. Northwest Science 79:106-119.

SALO, E.O. 1991. Life history of chum salmon. In: Groot, C., and Margolis, L., eds. Pacific salmon life histories. Vancouver: UBC Press. 311-394.

SHESTAKOV, A.V. 1991. Preliminary data on the dynamics of the downstream migration of coregonid larvae in the Anadyr River. Journal of Ichthyology 31(3):65-74.
1992. Spatial distribution of juvenile coregonids in the floodplain zone of the middle Anadyr River. Journal of Ichthyology 32(3):75-85.

- 2001. Biology of the broad whitefish Coregonus nasus (Coregonidae) in the Anadyr Basin. Journal of Ichthyology 41:746-754.

STEIGENBERGER, L.W., and ELSON, M.S. 1977. Northern Yukon fisheries studies 1972-1974. Fisheries and Marine Service Technical Report PAC T/77-4. 142 p.

STEIN, J.N., JESSOP, C.S., PORTER, T.R., and CHANG-KUE, K.T.J. 1973. An evaluation of the fish resources of the Mackenzie River valley as related to pipeline development, Vol. 1. Task Force on Northern Oil Development 73-1. 122 p.

THEDINGA, J.F., MURPHY, M.L., JOHNSON, S.W., LORENZ, J.M., and KOSKI, K.V. 1994. Determination of salmonid smolt yield with rotary-screw traps in the Situk River, Alaska, to predict effects of glacial flooding. North American Journal of Fisheries Management 14:837-851.

TODD, I.S. 1966. A technique for the enumeration of chum salmon fry in the Fraser River, British Columbia. Canadian Fish Culturalist 38:3-35.

USGS (UNITED STATES GEOLOGICALSURVEY). 2007. USGS surface-water data for the nation. Washington, D.C.: United States Department of the Interior. http://waterdata.usgs.gov/ usa/nwis/sw.

WALKER, C.E. 1976. Studies on the freshwater and anadromous fishes of the Yukon River within Canada. Fisheries and Marine Service Technical Report PAC T/76-7. 99 p. 